\title{
An evaluation of Iran architecture during first Pahlavi Era: A transition from tradition to modernity
}

\author{
Javad Eiraji* \\ Seyed Ahmad Reza Yekani Fard**(1)
}

\begin{abstract}
How to move from tradition to modernity and how to combine or control them in a society has a direct relationship with the culture and the culture, as the main tool of architecture, needs a transition. This transition was started to be appeared in Iran during first Pahlavi era, while the government was planning to develop this process. This research is a qualitative-descriptive one and it has a deductive style and the significance and aim of this research is to study the tradition and modernity in architecture and to see how the contemporary architecture of Iran tried to transit from tradition to modernity during first Pahlavi Era. In this paper, first we will have a quick review on Iran during first Pahlavi era and its contemporary social and political history and tradition and modernity in its architecture and then by studying the architecture of two famous foreign architects, Nikolai Markov and Andre Godard who were invited to the country by the government for reformation and modernization of architecture of the country, their modern architectural styles facing with traditional and national needs of the country and their solutions will be studied.
\end{abstract}

Keywords: tradition, modernity, contemporary architecture of Iran, First Pahlavi

\section{Introduction}

Tradition is a changeless and constant factor which has s historical continuity and it is related to the religious believe of a nation. It is a serious of creeds, believes, opinions and repeatable act which can be created by time and can be supported as the social and national values. Plurality, conservatism, variation, resistance, keeping the current positions, superstition, originality, destiny and religion are some main components and factors of tradition (Suzankar, 2015).

In the other hand, the descriptions that have been presented for modernity are varietal and even in some cases opposite of each other. It has been believed that modernity is the victory of human thought and defeat of traditional believes. According to this, modernity is a collection of cultural, political, economic, social and philosophic complexes. Many theorists believe that modernity is the way of Today`s life (Ahmadi, 2001). Modernity is the era which its main character is the ceaseless conversion (Nozari, 2001). In fact, the foundation of modernity is on the mutation of human`s look on himself and the world around (Ashoori, 2000). 
The modernity is a dipole theory and puts the modern society against the traditional society and without presenting any comprehensive description, it knows the West society as a modern one and introduce the third world countries as the traditional ones. According to this theory, in the third world countries there are some barriers that prevent the development. Some of these barriers are old superstitions and population increasing. Thus, this theory is searching for the internal reasons for justification of lag in a society (Behnam, 2007).

In this paper, before coming to the tradition and modernity in contemporary architecture of Iran, first we will have quick review of First Pahlavi era and its contemporary history and architecture and then we will come to the tradition and modernity process and the plans of government toward modernization

\section{The First Pahlavi Era: Modernity, National Identity, Globalization and Identity Crisis}

Iran, as country which has seen different histories, kingdoms and events, faced with modern from Safavid period and it became more serious during Qajar. But during Qajar period the lonely things was a blindly emulation. With no scientific background on the modernity, Iranian just started to copy what they were seeing from European and West countries. After Qajar kingdom, the Pahlavi Kingdom started to do the reformation and modernization of society and architecture of New Iran. Iran pre-modern architecture during first Pahlavi era was a multi-factor architecture, a combination of traditions, believes, climes, meanings and senses. In one hand the society was interested in the modern revolutions which were happening in West, in one hand the government wanted to develop the nationalism waves and tendencies in the country and on the other hand the people could not leave their traditions. But in this era the reformation and modernization of the country started and the government started to invite the foreign architects and also the Iranian architects who were graduated from European countries and had the experience of modernity. Even though still in this era the doubt and challenges between modern, national and traditional architecture still were going on, but at least the government in this era, by inviting foreign architects and also the Iranian architects who were graduated from European countries, could have a big effect on the architecture of the country.

\subsection{Reza Shah Pahlavi: The Reformation and Modernization of Iran}

The First King of Pahlavi Era, Reza Khan, was born in 1878 in North of Iran. He could get a political power by a military coup in 1920 and be the King of new Kingdom in 1925 (Purshalji, 2005). The first Pahlavi's era contains two especial periods. The first one (1920-33) which faced with the Kingdoms changes from Qajar to Pahlavi. The main attribute of this period was the attendance of modern and West-Educated ones like Abdolhosein Teymoortash and Nasroldole Firooz in government whom the king could start the modernization programs with them in the country. This period also contains long-time economic programs such as rail way, new education system of the country, the appearance and clothing changes and opposition with religious traditions. The Second era (1933-41) was called "The One-Person Regime" and the main attribute of this era was omitting the modern persons of pervious period who had gotten power in the next period. In this period also the projects which were planned were being done. In fact we should accept the year 1925 as the beginning of modernization in Iran "The New Iran" (Hedayat,2000).

This modernism has two bases: The first one denying the traditions and Iranian values which were laggard now and the second one the tendency to develop in urban development (Katuzian, 2006). From the ideological aspects, Reza shah and his governmental system, tried to use Pre-Islam thoughts and actuate the national feelings of people and reduce the effects of religion in society. Choosing the family name "Pahlavi" which was the language of country before Islam, Changing the name of country from "Persia" to "Iran" were some of his works which he tried to do to reach his goals (Seddigh, 2002). 
Reza shah's reformations and modernization plans contains three main groups: The economic, the official and the social. The most important action during the first Pahlavi kingdom was the construction of rail way. He was believed that the rail way was one of the most important factors of modernity of a country. Some of his other important action toward modernity was the education systems changes, dispatching the Iranian students to Europe, The foundation of university of Tehran and Iran museum and etc. Reza shah, after lots of works toward the modernization of the country, because of some political reason abdicated in 1941 and his son Mohammad Reza became the second king of Pahlavi kingdom (Izadi, 2003).

\subsection{Time, Needs and the Governmental National Identity in First Pahlavi Era}

Hegel believes that all historical events happen for two times. The first time happens in a tragedy case and the second time in a comic case and any attempt for repeating the history would come to the second case (Ashoori, 2005). The time always goes on and a society always wins and be successful which can understand the needs of its people and know the current time and place of that society. A great architecture always goes on with its time and in fact the time creates and changes the cultures, traditions, treatments and functional patterns. So, architecture, depends on a society and the time that its being created, can be different and from the identity view the time is the most important thing which is out of human's control and if we want to search for the meaning of identity in today's life, we should do it for the time of today. Because the human of today has its own knowledge about the past and today. The first Pahlavi era which was an introduction to modernity, started a new season of thought in Iranian identity. Because up to that time people were used to an especial kind of political and social relationship and this phenomenon caused some questions about the meaning of identity.

After modernity came to Iran, its architecture faced with a bilateral way. In one hand it was interested in West modern architecture and in the other hand it was losing its traditional and past architecture and because of that, the identity crisis and national identity was started to be discussed. In the other hand, the government was trying to resurrect the ancient architecture and culture of Iran and without paying attention to this point that the repetition of a history can 't create or change the identity of a society. The government was trying to exaggerate the past of Iran. Because by repeating a history its meaning can't change and just the appearance can be changed and it is not enough for creating an identity and in our today world which the originality is depended to change and mutation, this kind of identity creation is rejected (Ghotbi, 2008).

\subsection{The Effects of Globalization on National Identity: Identity Crisis}

Identity is an assortment of characters which can identify the equality and difference aspects between some factors and when we talk about identity, the types of it should be mentioned too. For example, about human, we can talk about his social or cultural identity and about building, we can talk about its functional, aesthetical or structural identity, but totally everything should have its own comprehensive identity. Even though the experiences and background of a spectator is very important but the comprehensive identity of a building should be possible for everyone to be recognized.

Globalization is a production of international relationships and tries to decrease the importance of internal identities and without paying attention to time and place, tries to connect the people of the world. In fact, it is a production of modernity (Faramarz, 2012). Because of economic, social, political and technologies transformations, cultures always are being changed and the globalization process always contains cultural mutations (Nazemolboka, 2012). Globalization has been described both as a process and a meaning which contains the West background and presents all countries as one (Pooladi, 2008). It is a new and complicated phenomenon and because of its multi-functional aspects, its main quiddity has not been cleared completely and it is hard to present a unique description for it, but generally it can be described as a production of time and place process which 
causes the people enter to a unit society (Golmohammadi, 2007). In fact globalization is the intensification of a social relationship all over the world which causes the societies, despite long distances, have effects on each other (Maleki, 2003) and these effects can contains political, social, cultural and event architectural (Waters, 2000). It develops the modernity functional attributes among the societies which were effected by its minor attributes before (Tamilson, 2008). So it is a part of modernity and by the time that a society tries to accept the modernity it should accept its parts too. But in a country such as Iran with an old civilization and traditions, it was hard to share its attributes or accepts the globalization rules and in the other hand the new kingdom was trying to insert the national identity of Pre-Islam in the country and this causes Iran and Iranian architecture faced with three ways: The Islamic architecture, The Pre-Islamic architecture and the Modern architecture of West and this caused the society and the architecture of the country faced with an identity crisis.

Even though Iran had gotten its own distinct identity in architecture during the past centuries, but because of the cultural confusion, Iranian architecture had an identification crisis by facing modernity during the first Pahlavi era (Motallebi, 2011). In another hand, identity has the same age of history and it was created by the time that human felt that he should know who he was. It is a factor that describes distinction, existence, entity and all the things which causes a recognition of a person, culture or society and talks about it (Hojjati, 2005). Identity is always being created by time and history. So, all new sciences, thoughts, experiences and technologies which human learns today, will be a part of his identity in future (Farasatkhah, 2000).

The contemporary society of Iran, after coming out of its traditional shell in this era, encountered with three different cultural layers: religious, national and modern civilization of West and in fact the tendency to use these three factors be side each other caused the basis of identity crisis in the country. About Iranian past architecture, its traditional process was held up to Qajar period. The significance of identity was not discussed seriously because there was no doubt about it and normally it happened when it has been questioned and comes to crisis level. After this era and by coming the West modernization to the country the meaning and identity of Iranian past architecture started to be questioned (Ahmadi, 2004). By inviting foreign architects and also Iranian ones who were educated in West architecture schools to the country during the First Pahlavi, as the government was interested in the West modern architecture, this case appeared more. The buildings which were designed in this era, even though had an Iranian and national appearance but identity crisis between the past identity which was started to be discussed and the new modern identity which was trying to bring to the country by this foreign architect, started to be seen (Sarami, 2000).

\section{The Magisterial Architecture of First Pahlavi: Suspension and Transition from Tradition to Modernity}

In the first Pahlavi era, the government tried to create a Quasi-Modernity in the society which was more in a magisterial format and contains four main factors: Laism, The classic nationalism, modernization and the obsessive of national paltriness. They were also some other factors such as military and industrial development which had effects on the architecture of this era. The military caserns and police officers, were the most important factors for king to show his power to people, became the main symbols of the cities as the mosques were during the Islamic eras. Before analysing the architecture of first Pahlavi era, we will have a quick view on three different prevalent styles of this architecture and then we will talk more about them (Table 1). 
Table 1 The First Pahlavi prevalent architectural styles (Source: Authors)

\begin{tabular}{|c|l|}
\hline \multicolumn{2}{|c|}{ The First Pahlavi Prevalent Architectural Styles } \\
\hline Style & Attributes \\
\hline $\begin{array}{c}\text { The Continuation of Late } \\
\text { Qajar Architecture }\end{array}$ & $\begin{array}{l}\text { The imitation of West architecture with no speculative background- Little changes in } \\
\text { materials and the construction techniques. }\end{array}$ \\
\hline $\begin{array}{c}\text { The Early Modern } \\
\text { Architecture }\end{array}$ & $\begin{array}{l}\text { This kind of architecture was brought to the country by the foreign architects which } \\
\text { were invited to the country by the government and also the Iranian architects who } \\
\text { studied aboard. Trying to pay more attention to the theories of the modernity. }\end{array}$ \\
\hline $\begin{array}{c}\text { The European Neo-Classic } \\
\text { with Persian Motives } \\
\text { (National Style) }\end{array}$ & $\begin{array}{l}\text { Encouragement of the people to support their national factors by the government and } \\
\text { use Iranian Pre-Islam motives and symbols and also have combination with the } \\
\text { European neo-classic architecture }\end{array}$ \\
\hline
\end{tabular}

Even though these styles seems to have differences but in all of these three styles the main aim was trying to be close to the culture and architecture of West but still Iranian liked to stay both Iranian and looks like European. Also about architecture they could not stay loyal tenet of modern architecture of fourth CIAM and after that "Tradition or Modernity" became the main challenge of Iranian architecture (Banimasud, 2012). Vartan Hovanessian, one of the famous architects of Pahlavi period in two of his papers "The Problems of Iranian Architecture" and "Iranian Architecture: New and National Style" tried to mentioned this problem and keep modern architecture and Iranian architecture beside each other smartly. He believes that modernity is a fact and a natural phenomenon and should be accepted by societies but it can't be the same in all of the societies and depends on social and climatic attributes of each country can be different. He believed that we should not have bigotry to the past and traditions and should see also the present and future and it shouldn't be intemperate (Hovvansian, 2000).

The Most important point of Pahlavi architecture was inviting foreign architects and also Iranian architect who were educated from Europe and West and the effects that they had on the architecture of Iran. Most of modern architecture bases tried to be done in architecture of Iran during this era. For example, using new materials such as concrete, steel and glass which were some of modern material started to be use more beside traditional architecture. Using new modern construction systems and also central thermal system of the building was being more and general theme of the life, culture and also architecture from interior mood was changing to exterior (Marefat, 2000).

Because of new functional relationship caused by new architectural academic methods, the importance of plan in architectural design was increased in this era. The long corridors started to be located in two or more sides of a building, especially in huge governmental and educational buildings. The linear method of functional relationship were solved. The locative importance of stairs both in entrance of buildings with its wide attributes and in the middle of building with its two sided and curved form was increased. The new forms of windows in residential buildings and high and continual ones in huge governmental buildings and a new description of privacy in architecture were seen. The balcony was at the external side toward the outside of building against the traditional case which were called "Ivan" and were toward the inside courtyard of the building. The high entrance of buildings were with high columns to show the majesty of ancient architecture of Iran and the modern and expressionist style of Europe. The permanence of traditional systems of construction and the Iranian ancient lithograph and ornamentation and also the West classic ornamentation in architecture also were also used beside these modern systems and the construction of street looked like the style of European 19th century style and the street architecture method was created and the urban symbols changes from cultural-traditional style to bulky governmental styles in this era. 
But as it mention the main and most important action of first Pahlavi government was inviting and using foreign architects and also Iranian architects who were graduated from European countries. The ones who had the experience of West and modernity. They mission in a country and atmosphere which wanted to keep its tradition and nationality in one hand and learning and using the modernity bases in the other hand was so hard but their effects on Iran modern architecture and its creation process is clear. In this paper, two of these foreign architects who had a big effect on modern architecture of Iran during first Pahlavi era, Nikolai Markov and Andre Godard, and the transition from tradition to modernity in their architecture will be studied.

\subsection{Nikolai Markov: The Transition from Traditional Architecture to Modern Architecture}

Nikolai Markov (1882-1957) was born in 1882 in Tbilisi, Georgia. He was graduated from the Academy of Fine Arts in St. Petersburg in 1910. He came to Iran in 1917 and after working in army, in 1921 he started his architecture career again and established his first architecture office in Istanbul Street in Tehran. By designing and making around twenty buildings during first Pahlavi era, he made himself one of the most important foreign architects of first modern period in Iran.

Nikolai Markov Architectural Style; In the first years of the entrance of modernity to Iran, there was a big challenge between modern style followers and ancient-national style followers. The first group believed that the architecture should be simple, unadorned and unaffected and should refuse the ornamentation and historical references, but the second group completely follows the historical and ancient styles and ornamentation. In such a bilateral case, the "Art Deco" was a lonely style which was a moderate and medial one which contains both old and new and it was why Markov chose this style in his architectural design methods. Also maybe as he was coming from a country farer than the central and main modern countries such as Italy, France, Germany and America, so he decided to enter this style of architecture cautiously. In the other hand, in a developing country which was faced with dichotomy, the "Art Deco" style could be the best choice. This kind of architecture lets the modernity elements be by historical ones and caused a free selection style for creating a coordinated architecture with different cultures. With his modern thought, Nikolai was interested in Iranian traditional methods and using native material and also elements of national and ancient Iranian architecture. In most buildings designed by Markov, the most important thing is using available technologies and materials such as brick, tiles, porter walls and etc (Figure 1).

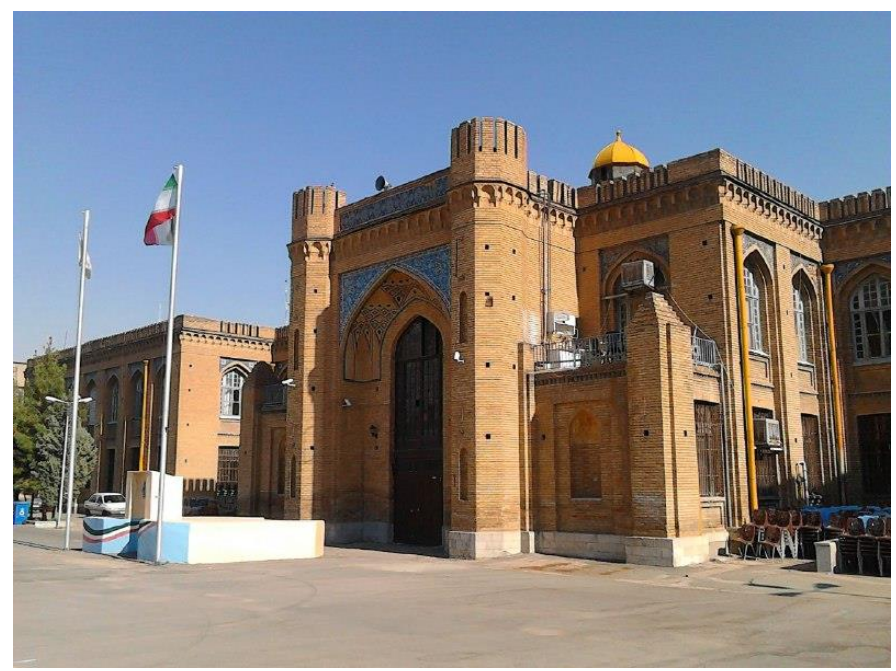

Figure 1 Modern thought and available traditional technologies and materials, Alborz High School by Nikolai Markov, Tehran

As it mentioned, even though in his period using new technologies were being used more, but in his style he tried to have mixture of new and traditional architectural technologies and using each for the other. For example he would try to use Iranian traditional arch by new modern technology 
and traditional experiences or using iron, light deck or metal which were the elements of modern architecture (Figure 2). Nikolai Markov was one of the numerable architects who could use and coordinate harmonic and eurhythmic combination of traditional Safavi architecture with ancient and modern design needs. His interest in Iran and Iranian architecture and also his tendency to Art Deco architecture and their coordinating with international processes caused growing and developing his style of architecture in Iran (Figure 3).

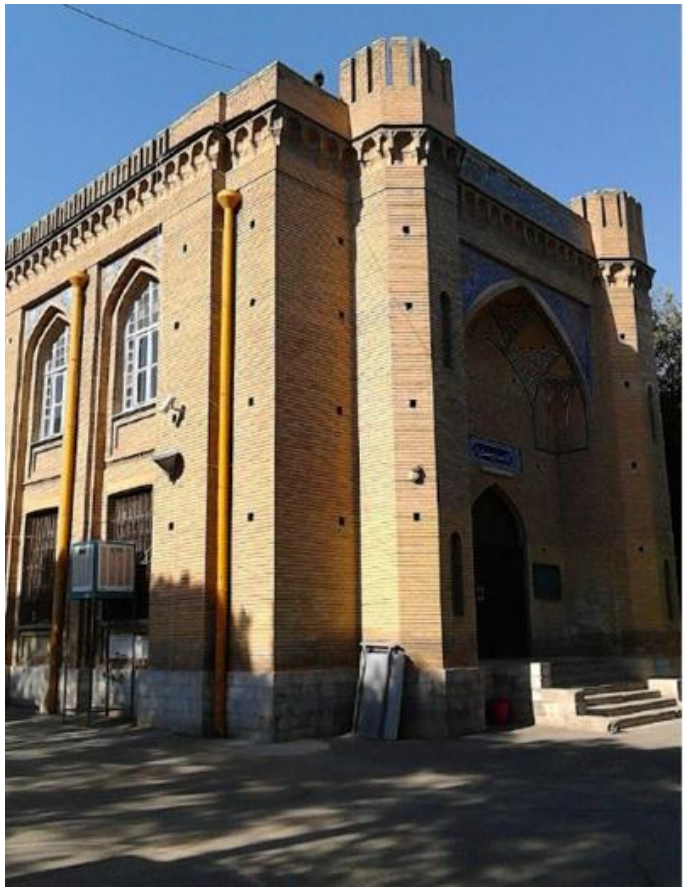

Figure 2 Using modern and tradition experiences beside each other

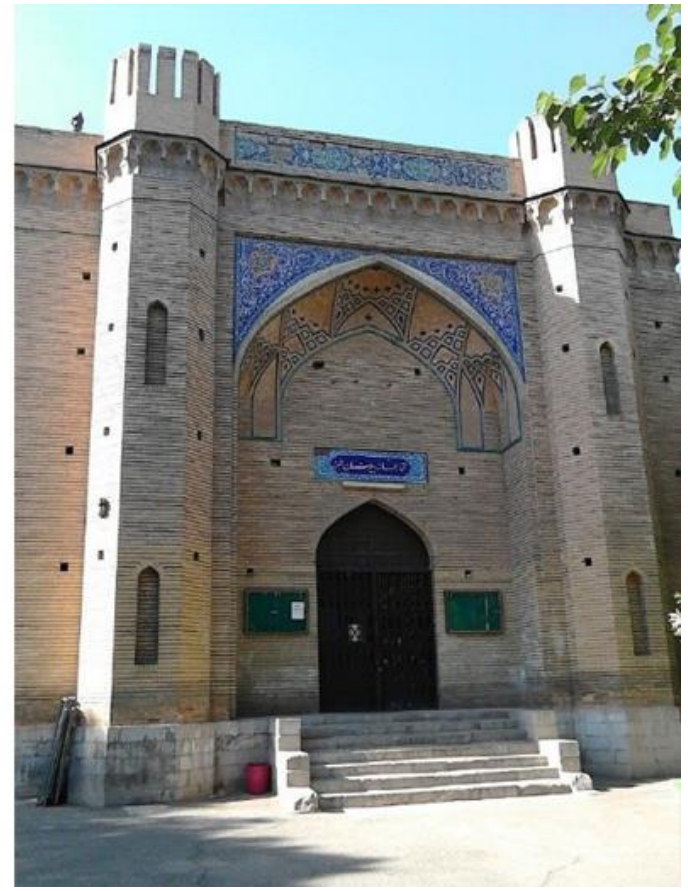

Figure 3 Islamic and Safavid architecture and West modern architecture

In one of his famous projects, "Alborz High School", he had tried to use European Neo-Classic architecture which was one of the most important styles of modern architecture beside Islamic traditional architecture of Iran [SAFAMANESH]. This building has an Islamic and Traditional appearance but in fact it has a modern functional usage. All the systems of the building are described and the horizontal and vertical connections also central part of the building are clear and these are all the things that a modern building needs it (Figure 4). The columns of the buildings are in European style but the capitals are completely Iranian (Figure 5).

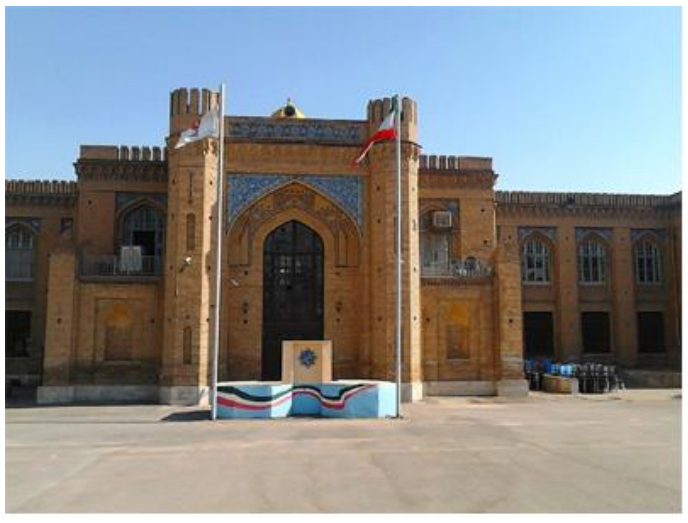

Figure 4 Islamic and traditional appearance and modern functions

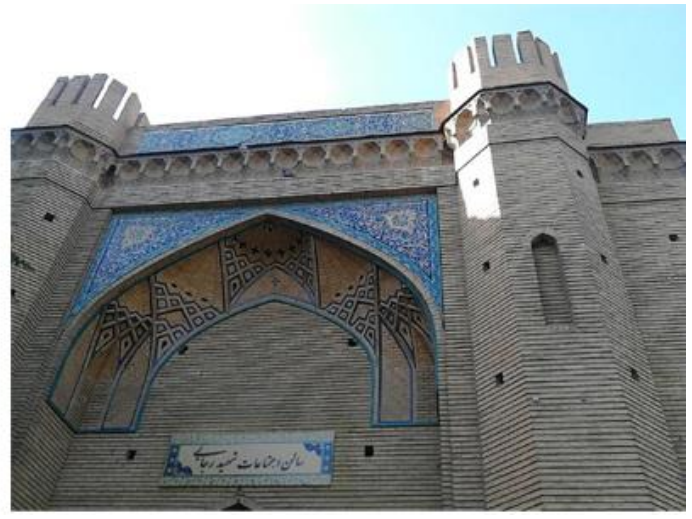

Figure 5 Alborz High School, The West Neo-Classic Architecture and Iranian Traditional Architecture 
By using Islamic and Safavi architecture traits, he could design some buildings with independent characters. Markov designed lots of other buildings such as Anooshirvan Dadgar High School, Amjadieh Sport Complex, Varamin Sugar Factory, Tehran Central and etc. His most buildings contains educational and governmental buildings. The main difference is that the weight of Iranian traditional architecture in his educational buildings were more and the weight of European classic themes were more in his public and official buildings. "The Singer Building", for example, is one of his official buildings which had used the European historical elements in the design of this building and can be in the category of international Art Deco style and can be used in any part of the world (Saffarmanesh, 2011). Dignity, elegance, poise, serenity, repetition and geometry are some important attributes of Markov's architecture (Figure 6). In his other project, Anooshirvan Dadgar High School, he had tried to use Iranian ancient symbols and in this project the weight of nationality is more. But like his other project he had managed the combination of tradition and modernity beside each other (Figure 7).

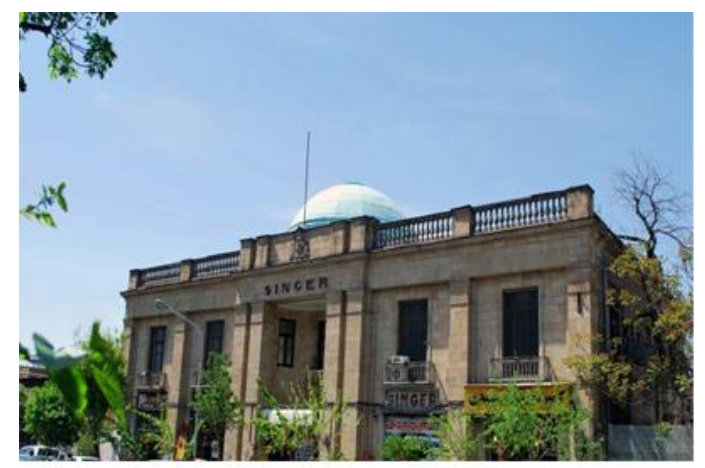

Figure 6 The Singer building by Nikolai Markov

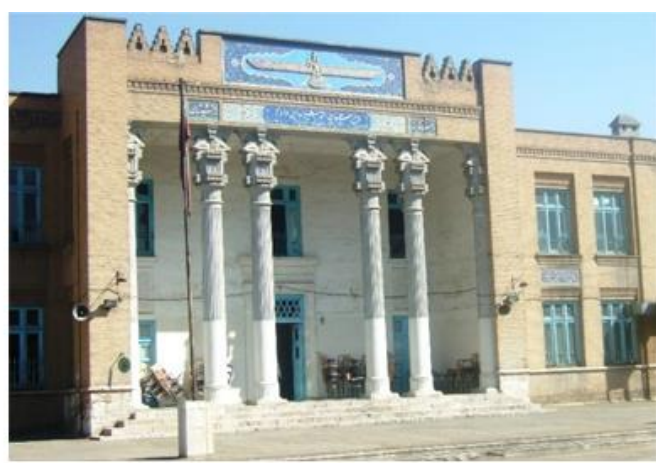

Figure 7 Anooshirvan Dadgar High School by Nikolai Markov, The modern architecture and Iranian ancient architecture

Totally, as he started to work in a time that the country had a big challenge with modernity, nationalism and tradition architecture and a big doubt to choose, Nikolai Markov's architecture could have a big effect on the architecture of that period of time and satisfied all three aspects. He came to Iran with a modern thought and his major was to develop national architecture and also people were accepting traditional more. So he had to have a fine combination of these three and depends on what kind of project he was doing the amount of each aspect was changing (Table 2).

Table 2 Nikolai Markov`s architecture style

\begin{tabular}{|c|c|c|}
\hline Style & Example/Premier Aspect & \\
\hline $\begin{array}{c}\text { Modern Architecture (Neo- } \\
\text { Classic)+ Traditional Islamic } \\
\text { Architecture }\end{array}$ & $\begin{array}{c}\text { Alborz High School/Traditional Islamic } \\
\text { Architecture }\end{array}$ \\
\hline $\begin{array}{c}\text { Modern Architecture + Iranian } \\
\text { National Pre-Islam Architecture }\end{array}$ & $\begin{array}{c}\text { Anooshirvan Dadgar High School / } \\
\text { Iranian National Pre-Islam } \\
\text { Architecture }\end{array}$ \\
& & \\
& &
\end{tabular}




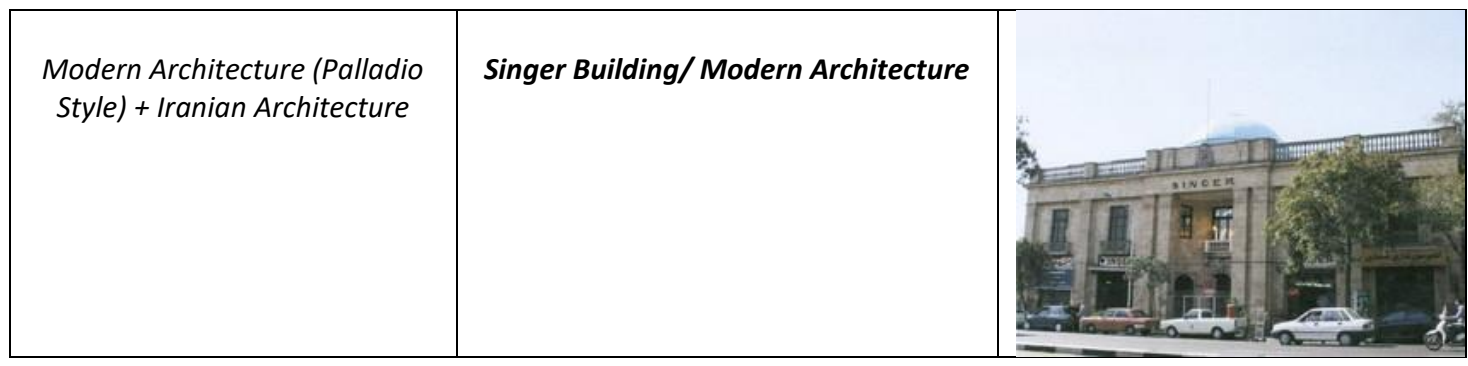

Page | 230

\subsection{Andre Godard and his Traditional-Modern Point of View in Iranian Architecture}

Andre Godard, French archeologist and architect, was born in Chaumont in 1881. A graduate of the École des Beaux-Arts of Paris, he studied Middle Eastern archaeology, particularly that of Iran, and later became known for designing the National Museum of Iran, where he was appointed inaugural director in 1936. He was also instrumental in the design of Tehran University campus. He made his first trip to the Middle East in 1910 with Henri Violle. Together, they began to excavate the ancient ruins of Samarra, located in modern-day Iraq. The ruins were fully excavated a few years later by German-born archaeologist Ernst Herzfeld. Godard returned to his architectural studies in 1912, focusing on Islamic architecture of Egypt. After World War I, Godard married Yeda Reuilly. The Delegation of French Archaeology in Afghanistan was subsequently founded in 1922, so Godard and his new wife accompanied the organization to not-yet-excavated regions. They consequently studied Bâmiyân, which was later permitted to be exhibited at the central Buddhist shrine of the Guimet Museum, in 1925.

In 1928, Godard was granted the directorship of Iranian Archeological Services, by the authority of First Pahlavi King. The IAS was intended to mark the end of French monopoly over excavation in Iran. As such, Godard focused on the politics of conservation, and held the title of Director from 1928-1953, then again from 1956-1960. The Pahlavi king also appointed him as the director of the National Museum of Iran (Muze-ye Irân-e Bāstān). During his tenure, Godard was responsible for the restoration of major historic monuments of Iran, such as the Friday Mosque, the Shah Mosque, and Mosque of Sheikh Lutfallah of Isfahan among others. Using his directorships, he organized mass excavations, such as the bronzes of Lorestan, Persepolis and Isfahan. Godard believed that art and architecture are the main bases of any culture and they reflect the human spirit and the main thing in the spirit of art and architecture is the spirit of that society. He believed that architecture is not just a traditional combination of brick and stone and in his idea, architecture is production of thoughts (Musavi Gilani, 2009).

One of reasons that Godard was chosen by government to design the most important buildings of the country was his high level education and experience in the architecture of East and as the government main program was to keep the traditional identity beside the process of the West modernity, he was the best candidate to reach the government aims in the field of architecture. Godard designed lots of monumental and cultural buildings which in most of the showing modernity beside the traditional and national elements of Iranian architecture can be seen. To seek these elements and this mixture in his architecture one of his famous project "Iranshahr School" in Yazd will be studied. 


\subsection{Andre Godard and The Iranshahr School in Yazd, Iran}

The Iranshahr School, designed by Andre Godard and Maxim Siro, in 1935 in Yazd, is one of the best examples of Godard's work which he has tried to show his knowledge in Iranian traditional architecture and to create a balance between tradition and modernity in Iranian architecture (Figure 8).
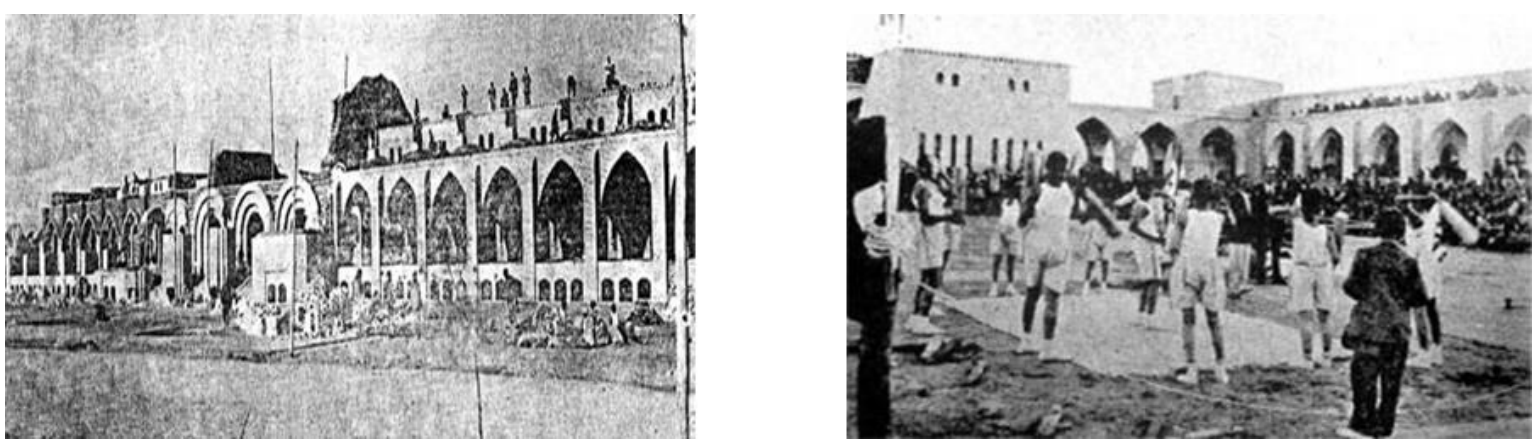

Figure 8 The Iranshahr School by Andre Godard and Maxim Siro

This school was designed in two stores. The ground floor was the main floor and the main spaces were designed there and the underground floor which was designed for laboratories. The main materials in this school are brick and stones and the space organization of the building is traditional. Using Iranian arch in the main elevation of the building and also portico and porch, lead the building toward Iranian traditional sustainable architecture factors. Repetition and harmony are some other architectural traits of this building (Figure 9). One of the other architectural traits that can be seen in this project is transparency that has been created by its balcony and also the building 's simple, extended and symmetric façade (Figure 10).

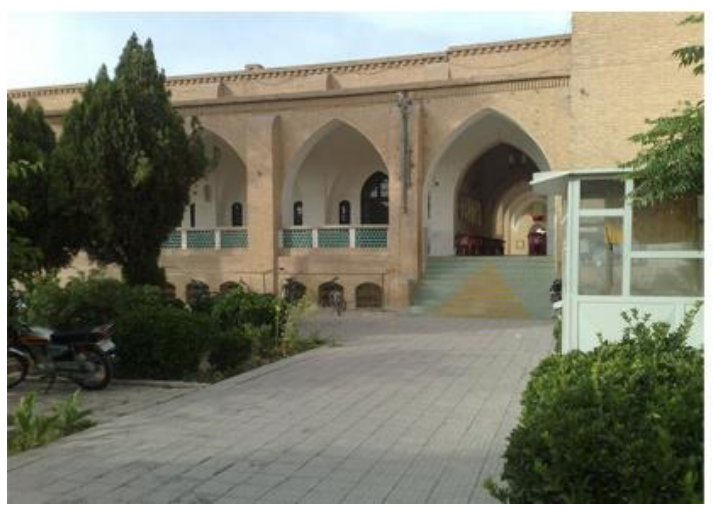

Figure 9 Traditional Factors in the Architectural

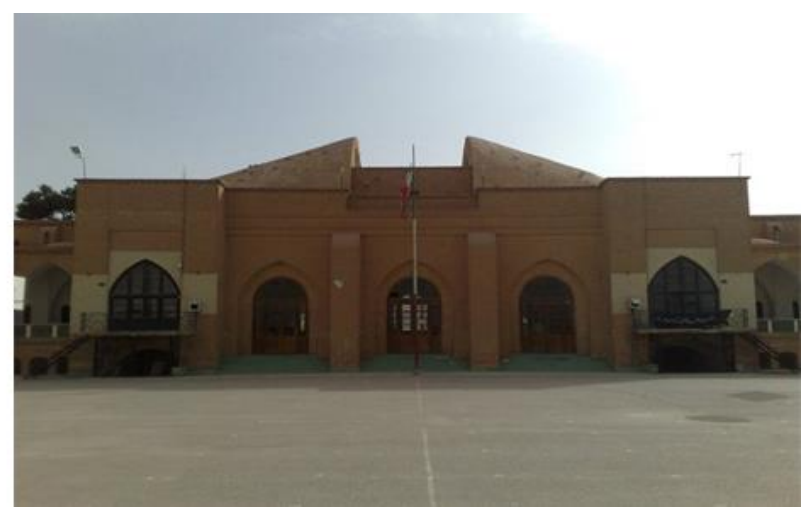

Figure 10 The Façade of the Main Building of Iranshahr School Design of Iranshahr School

According to the mentioned points, the main traits of Andre Godard's architecture in encountering with tradition and modernity and its reflection on the architectural design of Iranshahr school can be concluded as follows (Table 3 ).

Table 3 Andre Godard`s Characteristics of Traditional and Modern Architectural Tendencies in Iranshahr School

\begin{tabular}{|c|c|c|}
\hline \multirow{2}{*}{$\begin{array}{c}\text { Andre Godard 's Traditional- } \\
\text { Modern Architectural Points of } \\
\text { View }\end{array}$} & \multicolumn{2}{|c|}{$\begin{array}{c}\text { Characteristics of Traditional and Modern Architectural Tendencies of } \\
\text { Iranshahr School }\end{array}$} \\
\cline { 2 - 3 } & $\begin{array}{c}\text { Characteristics of Traditional } \\
\text { Architectural Tendencies }\end{array}$ & $\begin{array}{c}\text { Characteristics of Modern } \\
\text { Architectural Tendencies }\end{array}$ \\
\hline
\end{tabular}




\begin{tabular}{|l|l|l|}
\hline $\begin{array}{l}\text { Equality in Traditional and Modern } \\
\text { Characteristics in Architecture }\end{array}$ & $\begin{array}{l}\text { The Utilization of Iranian } \\
\text { Traditional Arch, Portico and Porch }\end{array}$ & $\begin{array}{l}\text { Simple, Extended and Symmetric } \\
\text { Façade }\end{array}$ \\
\hline $\begin{array}{l}\text { Showing the Spirit of Human and } \\
\text { Society in Architecture }\end{array}$ & $\begin{array}{l}\text { Harmony, Rhythm, Traditional } \\
\text { Sustainability Factors }\end{array}$ & $\begin{array}{l}\text { Transparency, The Relationship } \\
\text { between Outside and Inside of the } \\
\text { Building }\end{array}$ \\
\hline $\begin{array}{l}\text { A Mixture Combination of } \\
\text { Materials and Colors }\end{array}$ & Stone, Brick, Brown, Yellow & Stone, Brick, Glass, Brown, Yellow \\
\hline $\begin{array}{l}\text { Space Specialization and } \\
\text { Organization }\end{array}$ & $\begin{array}{l}\text { The Main Functional Space on the } \\
\text { Ground Floor }\end{array}$ & $\begin{array}{l}\text { The Laboratories on the Underground } \\
\text { Floor }\end{array}$ \\
\hline
\end{tabular}

\section{Conclusion}

Modernity is transient, fleeting and contingent because it is about the present states of affaires. Nothing maintains its quality and status throughout time; states of affaires are constantly changing. Therefore, something is modern only in relation to its situation in time and space. It seems to be a dichotomy between modernity, as the changing, and tradition, as continuity. But it is clear that together they constitute social practices, since these are -pretty much always -changing, but yet, they do so within a continual context.

In this paper, first we reviewed the main descriptions of tradition and modernity which were presented by related theorists. Then, we focused on the combination of tradition and modernity in the architecture of some Islamic countries in East and some Western countries in Europe. Next, we had a review on first Pahlavi era, the modernity process which was started from Qajar era and was being organized in this era, the national identity which the government was trying to develop and the globalization which the society faces and its effects which caused identity crisis. Then we talked about the reformation and modernization that Reza shah started to do in the country and the magisterial architecture of this era and the foreign architects` effects on this architecture which were invited by the government to the country. Then by studying the architecture of two famous foreign architects, Nikolai Markov and Andre Godard, it was concluded that these architects, by the modern experience that they had and also by a correct management and organization in their architectural designs could satisfy and manage all three needed aspects of the architecture, modernity, nationalism and tradition, which were needed in this era and could have a great effect on the architecture of Iran to transit from tradition to modernity.

\section{References}

Ahmadi. B. (2001). Modern Architecture, Markaz Publication, Tehran, 22-25.

Ahmadi. F. (2004). Searching for National Identity in Today's Architecture: Yes or No, No. 25, Memar Nashr, Tehran.

Ashoori. D. (2005). We and Modernity, The Cultural Institute of Serat, Tehran, 21-25.

Ashoori. D. (2000). We and Modernity, Serat Cultural Publication, Tehran, 40-65.

Banimasud. A. (2012). The Contemporary Architecture of Iran, Honere Memarie Gharn Publication, Tehran.

Behnam. J. (2007), Iranian and The Modernity Thought, Foroozan Rooz Research and Publication, Tehran, 2426.

Faramarz. M. (2012). The Functional Development of Iran Contemporary Architecture in Encountering with Globalization, First New Thoughts and Technologies in Architecture, Tabriz, 15-18.

Farasatkhah. M. (2000). Identity and Derivation Contradiction, Iran-e-Farda, Tehran, 1993.Eylül Üniversitesi, İzmir, Nisan 26-27.

Ghotbi. A. (2008). The Meaning of Identity and Architecture of Contemporary Iran, Ayineh Khial, Tehran, 1418.

Golmohammadi. A. (2007). The Globalization of Culture, Nashr-e-Ney, Tehran, 19-25.

Hojjati. I. (2005). A Thought on The Relationship of Identity and Architecture, Journal of Fine Arts, Vol. 24, Tehran, 24-23.

Hedayat. M. (2000). The Memories and Dangers: The History of Six Kings and a Part of My Life, Zavvar, Tehra. Hovvansian. V. (2000). Iran Architecture: New and National Style, The Journal of Art and Architecture, Vol. 1, Tehran, 33-38.

Izadi. A. (2003) The Memories of Ali Izadi: The Death of Reza Shah, Tarh No., Tehran, 30-32. 
Katuzian. H. M. (2006), The Political Economy of Iran, Markaz, Tehran, 16-26.

Maleki. M. (2003). The Economic Globalization: From Dream to Reality, Contemporary Science and Thought Publication, Tehran, 23-27.

Marefat. M. (2000). The Ones Who Formed Modern Tehran, The Technical and Engineering Organization of Tehran, Tehran, 103-137.

Motallebi. Gh. (2011). Identity Crisis in Iran Contemporary Architecture, Second National Conference on Islamic Architecture and Urban Design, Tehran, 11-20.

Musavi Gilani. S. (2009). Islamic Art from Godard`s View, Memaran, Tehran, 9-12.

Nazemolboka. M. (2012). From Global City to Global Village, First National Conference on New Thoughts and Technologies in Architecture, Tabriz, 35-38.

Nozari. H. (2001). Modernity and Modernism, Naghshe Jahan, Tehran, 11-27.

Pooladi. K. (2008). Globalization and Cultural Identity, The Research Monthly, Vol. 19, Tehran, 101-122.

Purshalji. M. (2005). The Cossack of Reza Pahlavi Shah Era According to Ministry of Foreign Affairs of France, Morvarid, Tehran, 55-65.

Safamanesh. K. (2011). Alborz High School, Zibasazi Shahrdari Tehran, Tehran, 11-25.

Sarami. A. (2000). Modernity and Its Effect on Architecture and Urban Design of Iran, Goftogu, Tehran, 2230.

Seddigh. I. (2002). The History of Iran Culture: From First to Now, Tehran University Press, Tehran, 22-25.

Tamilson. J. (2008). Globalization and Cultural Identity, Identity Research Journal, Vol. 19, Tehran, 139-156.

Waters. M. (2000). Globalization, Tehran Industrial Management Organization Publication, Tehran, 22-25.

\section{Resume}

Javad Eiraji received his PhD degree from Central Tehran Branch, Islamic Azad University, Tehran, IRAN in 2017. Javad who has been the Assistant Professor and Head of Architecture Department in Islamic Azad University for 5 years, has been started to work with Eskisehir Technical University, Eskisehir, Turkey as visiting lecturer. Javad has various articles which are published in both national and international academic journals which focus on Identity, Tradition and Modernity in Architecture, Contemporary Architecture and Sustainability.

Seyed Ahmad Reza Yekani Fard who has been the Assistant Professor and Head of Urban Planning Department in Islamic Azad University-Dubai Branch for 7 years, has been started to work with Eskisehir Technical University, Eskisehir, Turkey as visiting lecturer. Reza has various articles which are published in both national and international academic journals which focus on Urban Planning and Design 